Article

\title{
Stormwater Utility Fees and Credits: A Funding Strategy for Sustainability
}

\author{
Jerry Zhirong Zhao ${ }^{*, t, \ddagger}+$, Camila Fonseca ${ }^{t, \ddagger}$ and Raihana Zeerak ${ }^{t, \ddagger}$ \\ Humphrey School of Public Affairs- University of Minnesota, 301 19th Ave S, Minneapolis, MN 55455, USA; \\ fonse024@umn.edu (C.F.); zeera001@umn.edu (R.Z.) \\ * Correspondence: zrzhao@umn.edu; Tel.: +1-612-625-7318 \\ + Current address: Hubert H. Humphrey School of Public Affairs, 301 19th Avenue South, \\ Minneapolis, MN 55455, USA. \\ $\ddagger \quad$ These authors contributed equally to this work.
}

Received: 13 February 2019; Accepted: 26 March 2019; Published: 30 March 2019

check for updates

\begin{abstract}
Lack of stable and dedicated funding has been a primary challenge for municipalities in the United States to implement effective stormwater management programs. Stormwater utility fees (SUFs), as user fees, are an alternative dedicated revenue source to fund stormwater management. When complemented with stormwater utility credits or discounts, SUFs provide greater flexibility to adopting best management practices and reducing stormwater runoff at a lower overall cost to the community. While SUFs have been increasingly used, there is little systematic research on this topic. This paper reviews literature on how SUFs work, discusses the mechanisms for setting the fees, and provides examples of different rate structures from across the U.S. Then, we use the findings of the literature to evaluate SUFs as a funding strategy for stormwater management based on four revenue evaluation criteria of efficiency, equity, revenue adequacy, and feasibility. Overall, the literature indicates that stormwater utility fees are a more efficient and environmentally sustainable source of revenue that allows for long-range planning of capital improvements and operations, but their high political visibility and legal obstacles can affect their effective implementation. However, more empirical research is needed to assess these propositions. There is a lack of literature on effective SUF designs, equitable fee types, the extent to which SUFs lead to change in public behavior and their impact on business and stormwater management investments in a municipality.
\end{abstract}

Keywords: stormwater management; stormwater finance; stormwater user fees; revenue evaluation; infrastructure finance

\section{Introduction}

Increasing urban development has led to increased stormwater runoff and water pollution [1]. Developed land prevents stormwater from soaking into the ground. Therefore, stormwater runoff from the impervious areas along with pollution flow into natural water bodies without being treated. This untreated stormwater can result in contamination of drinking water supplies, threatening both human life and wildlife; as well as changes in stream ecosystems, and ecological degradation such as erosion, and increased flooding, especially during extreme weather conditions [2-4].

To address water pollution and protect water quality in the United States, the U.S. Congress passed the Clean Water Act (CWA) of 1972. This act focused primarily on wastewater and industrial discharge but did not specifically address stormwater [5]. In 1987, the CWA was amended through the Water Quality Act 
(WQA) that mandated the implementation of a comprehensive national program to address stormwater runoff (enacting implementation and funding). These regulations, however, did not ensure a stable or dedicated source of funding for the necessary improvements to the stormwater system. Traditionally, in the U.S., stormwater management funding has come from the general fund, a primary government fund that is not allotted for a special purpose, and whose main revenue source is property taxes. Therefore, in the allocation of funding, stormwater management competes with other pressing local services [6,7], and usually receives low priority and its funding is often inadequate [6].

Lack of funding has been one of the primary challenges to implementing effective stormwater programs [8,9]. Insufficient funding affects not only the construction of new facilities but also keeping the old systems functional [10]. This problem is further exacerbated by the rising costs to manage stormwater [11]. Due to lack of funding and the increasing costs of providing stormwater management, local governments face challenges to comply with the federal and state regulations and improve stormwater quality. In the absence of adequate revenues, municipalities have used other methods to fund their stormwater projects, including special assessments, development fees, impact fees, permits and inspection fees [9]. In recent years, stormwater utility fees have been increasingly used by local government as an alternative revenue source to implement sustainable stormwater programs.

Stormwater utility fees (SUFs) were first introduced in the U.S. in the 1970s but were not widely used until the 1990s [11,12]. SUFs are used to generate dedicated revenue to meet the increasing demand for investment in stormwater management, including planning and operations, and new capital construction and improvements $[11,13]$. Their use in the U.S. increased with the amendment of the Clean Water Act (CWA) in 1987, which compelled many municipalities to seek alternative funding sources for stormwater management. In the last decade only, the number of municipalities with SUFs in the U.S. has increased more than 150 percent, from 635 in 2007 to 1681 in 2018 [14,15]. Following the American example, some municipalities in Canada have also adopted SUFs in recent years [16]. In 2018, 29 SUFs were identified in Canada [15]. Similarly, other countries such as the United Kingdom, Germany, and Australia have stormwater programs similar to the U.S. [17]. However, the focus of this paper is to discuss stormwater utility fees specifically in the U.S.

Previous research suggests that, compared to the use of general revenue, stormwater utility fees provide a more equitable and stable source of revenue $[13,18,19]$. Research on this area, however, is limited and outdated. In this paper, we conduct a comprehensive research on stormwater utility fees as a funding strategy for sustainable stormwater management. This paper is organized as follows. The next section presents a literature review on stormwater utility fees. In Section 3 we connect surveys with academic research and provide real examples to discuss how stormwater utility fees are designed and implemented across the U.S. Section 4 assesses stormwater utility fees as a revenue strategy based on four criteria: efficiency, equity, revenue adequacy, and feasibility. In Section 5, we propose a research agenda and call for more empirical research to answer several critical questions. Finally, we summarize and conclude in Section 6. The paper may inform municipalities in the U.S. as well as in other countries that are considering or in the process of implementing SUFs.

\section{Literature Review}

In the U.S. stormwater runoff has traditionally been controlled through underground pipelines ("gray infrastructure") that are supported with general-fund allocation. In recent decades, there are additional efforts to engage the participation of property owners for the adoption of stormwater Best Management Practices (BMPs). Aiming to prevent and reduce water pollution [20], these BMPs may include measures such as rain gardens, wetlands, green roofs and walls, trees, pervious pavement, and on-sight rainwater storage $[12,21,22]$. 
Existing literature on stormwater management finance mainly consist of government manuals, implementation guidelines and reports, particularly from the Environmental Protection Agency (EPA) and local governments. In recent years a number of surveys have been published including the Black and Veatch and the Western Kentucky University stormwater utility surveys. The Black and Veatch biennial surveys assess stormwater management, finance, and governance; while the Western Kentucky University surveys explore fee setting, and maintain an up-to-date database of SUFs in the U.S. and Canada.

With the proliferation of stormwater utilities since the 1990s, several academic articles have been published on stormwater utilities, yet academic literature on SUFs as a funding strategy is limited. Earlier studies focus on the potential benefits of user fees in terms of equity, efficiency, and acceptability, as well as the potential use and the challenges to adopt them in different contexts. Lindsey [6] estimates the potential for construction of on-site BMPs in different types of properties by comparing the costs of construction and maintenance of BMPs with the costs of implementing SUFs in Maryland. His findings suggest that only industrial users would consider the construction of on-site BMPs. Cameron et al. [10] review the experience and the institutional and legal issues of SUFs in the U.S. and present considerations for the implementation of SUF in Canada. The authors find that SUFs in Canada would be comparable to those implemented in the U.S. and highlight start-up costs and public perceptions as potential obstacles for implementing SUFs. Busco and Lindsey [23] develop a web-based resource center for municipalities interested in financing stormwater management. Brisman [24] discusses the benefits and challenges that municipalities faced or should consider when implementing SUFs. According to the author, SUFs have the advantage of raising revenue and educating the public; however, the process of establishing them is long and requires political will and support from the public. Grigg [17] assesses changes in stormwater organization and finance. In terms of finance, the author concludes that the main advantages of SUFs are that they create a new revenue stream, and enable municipalities to assign charges based on the benefits they receive.

More recent studies analyze the impact of municipal characteristics on the SUF funding structures. Kea et al. [25] analyze the relationship between location, population density, home value, and SUF characteristics, and identify trends and patterns in the establishment, funding mechanisms, and magnitude of SUFs. Fedorchak et al. [5] analyze the application of eight SUFs in Virginia to determine the impact of land use on the sources of revenue. Other studies have focused on the use and economic efficacy of stormwater credits to incentivize users to adopt BMPs. Doll et al. [26] review credit approaches by providing examples of municipalities that implemented credits or discounts along with SUFs for on-site stormwater management. Thurston [27] studies the opportunity costs of residential BMPs for stormwater runoff control in a pilot study. The author finds that while the implementation of BMPs reduces the amount of stormwater significantly, the overall municipal cost of stormwater management increases when considering construction and maintenance costs, as well as the opportunity costs of taking a parcel of land out of other uses. Kertesz et al. [28] study the hydrologic and economic efficacy of four stormwater utility credit programs for installing BMPs.

Research on SUFs as a funding strategy is limited and scattered. While reports on stormwater management often mention SUFs, there is very limited reference in academic literature about how the financial instrument are designed, where its has been utilized, and whether it is effective and sustainable for stormwater management. These questions are critical for municipalities that are considering the adoption of SUFs. To fill this gap in the literature, this paper will conduct a comprehensive research on stormwater utility fees and credits as a funding strategy for sustainable stormwater management. 


\section{How Are Stormwater Utility Fees Designed and Implemented?}

SUFs are user fees that users pay for their use of the stormwater management system. One of their most important features is that revenues from SUFs are specifically dedicated to stormwater management [13], either for stormwater capital infrastructure or operations and maintenance, or both [12]. All properties within a jurisdiction are required to pay the fee, including those that are tax-exempt.

In the U.S., a total of 1681 SUFs, mostly adopted by cities and counties were identified in 2018, with a higher concentration in Minnesota, Florida, Wisconsin, Washington, Iowa, Ohio, and Texas, all of them having more than 100 SUFs [15]. These are typically concentrated in urbanized areas and serving populations under 50,000 residents [29]. While the number of SUFs in 2018 shows a significant increase compared to the numbers a decade ago when there were only 635 [14], this number shows that less than 10 percent of the cities and towns in the U.S. have adopted SUFs.

\subsection{SUFs Authorization and Administration}

Almost all states in the U.S. provide municipalities with the legal authority to enact and administer stormwater programs and assess user fees [30]. The authority is usually derived from an enabling statute enacted by the state legislature or via the constitution of the state [30]. While in some municipalities, the state authorization is sufficient to assess SUFs, some other municipalities require voter approval. For instance, municipalities in California that want to collect local fees require voter approval through a public referendum, following the Proposition 218 on Requirements for Property-Related Fees [31].

In addition to variations in state laws, the administration of the fee also varies across states. States commonly use two models for the administration of the fee, the utility model or the public works model, depending on their local priorities and political situations [17]. For instance, in some states, such as in Connecticut, authorities create a stormwater utility district as a special assessment district that imposes a user fee to fund stormwater management [32]. In this case, the utility district can act independently of the local politics and administration associated with the general fund and general taxation process. In other states, the Department of Public Works of the cities or counties administers the fee to properties within the city or county limits (e.g., Minneapolis, MN; Athens-Clarke County, GA).

\subsection{SUFs Rate Structure}

SUFs are charged to consumers as a flat rate or a variable rate based on the consumers' use of stormwater management services [25].

In a flat rate structure, the consumer pays a fixed amount for the use of stormwater management services regardless of the actual usage. There are two methods to assess the fee in this structure, a flat or tiered fee. Under a flat fee, consumers pay the same fee amount. The use of flat fees is more common for residential properties [33] and has been the funding mechanism in small towns and popular in municipalities with lower home values [25]. In 2018, 236 SUFs were identified in the U.S. using the flat fee method with fees ranging from less than $\$ 0.001$ to $\$ 69.25$ monthly, based on stormwater needs and local political realities [15]. In tiered fees, all properties are categorized -by use or size of the propertyand charged accordingly. Tiered fees are most commonly used only in non-residential properties due to administrative challenges [33]. These types of rates are the second most popular systems in the U.S. with 241 SFUs identified in 2018 [15].

In a variable rate, the system usage is determined by the volume of stormwater runoff produced by the consumer's land. Several parameters, some of them directly related to the amount of runoff, may be used by the municipalities to determine the usage of the system including the impervious area, the percentage of imperviousness, the amount of runoff, the water consumption, and the intensity of development among others. The most commonly used parameter is the impervious area on a property $[5,13,18]$. 
There are several methods used for the calculation of the fee (see Table 1), but there are two methods that are more commonly used: the Equivalent Residential Unit (ERU) and Residential Equivalent Factor (REF). First, the Equivalent Residential Unit (ERU), also known as the Equivalent Surface Unit (ESU) method, is calculated based on the average impervious area on residential parcels in a municipality $[5,34,35]$. The cost for each parcel is calculated based on the parcel impervious area as a share of the ERU area. To determine the number of billable ERUs for non-residential parcels, their impervious areas are divided by the impervious area of a typical residential parcel [18]. This method has been the most prevalent funding mechanism in the U.S., particularly in larger cities with high population densities [25]. According to Campbell [15], there were 786 ERU utilities identified in the country in 2018. Second, in the Residential Equivalent Factor (REF) method, fees are calculated based on the amount of runoff [5]. The REF is determined by the ratio of runoff volume generated by one acre of land to runoff volume generated by one acre of low-density residential land [36]. The monthly charge that a property pays is determined by the REF, the base rate, and the net area. This method is popular in municipalities with higher home values [25].

Overall, SUFs can be very flexible and tailored to local needs either as a variable rate or as a flat rate. Municipalities may also employ a combination of these methods based on their needs. For instance, many municipalities adopt a flat fee for residential properties and a variable fee for non-residential property types, with variations in fee calculations $[13,33]$ (see Table 1).

\subsection{Utility Fee Credits and Discounts}

In some municipalities, SUFs are complemented with stormwater utility discounts. These discounts promote private stormwater management [37] and allow the managing authority greater flexibility in protecting water quality and aquatic habitat in urban watersheds at a lower overall cost to the community [26]. Almost 50 percent of the SUFs in the U.S. are complemented with a stormwater credit program [38], generally available only to nonresidential property owners [26].

Municipalities commonly offer two types of credits and discounts: for impact reduction and cost reduction [34] (see Table 2). The first type of credits are offered to properties that implement BMPs to reduce stormwater runoff volume or to improve runoff quality. For instance, the city of Minneapolis, MN offers up to 50 percent credit to customers that implement on-site stormwater management that improve water quality and 50 or 100 percent credit for practices that address stormwater quantity [34]. Similarly, the City of Urbana, IL offers credits to property owners that adopt BMPs such as runoff reduction or runoff volume reduction ( $20 \%$ credit), runoff water quality $(10 \%$ credit), and direct discharge into a stream not maintained by the City (50\% credit) [39]. The second type of credits are less common, and are offered to private entities that provide public education and outreach or take on maintenance responsibility. For instance, the City of Urbana, IL offers credits to institutions that provide approved stormwater educational program for students ( $\$ 5$ credit per student-maximum 50\% discount) [39].

Few municipalities, in addition, provide greater flexibility through stormwater credit trading programs. These programs allow developers to meet the stormwater retention requirements on-site or purchase credits from others who have voluntarily adopted BMPs in their properties through a stormwater trading program [40]. These volunteers supply retention options at a relatively low-cost. For small local governments, however, these markets can be costly to establish, administer, and enforce [40]. The District of Columbia, for instance, has created a stormwater credit trading program. Volunteers can sell stormwater retention credit (SRC) to the Department of Energy and Environment (DOEE) through the SRC Price Lock Program, where individuals interested in selling the credit must meet eligibility requirements and complete the certification process. Volunteers can also sell their credits in an open market to private property owners. Prices for the Lock program are determined based on (i) the location of the project in the 
Municipal Separate Stormwater System (MS4), depending on the type and vulnerability of the stream; and (ii) the length of the agreement. The price for the first six years is expected to help recover the costs of BMPs development and installation, and the next six years to cover maintenance costs.

Table 1. SUFs Rate Infrastructure.

\begin{tabular}{|c|c|c|}
\hline Fee Type & Characteristics & Example \\
\hline \multicolumn{3}{|l|}{ Flat Rate } \\
\hline Flat fee & $\begin{array}{l}\text { Fixed amount for all users of the } \\
\text { stormwater system }\end{array}$ & $\begin{array}{l}\text { Clayton County, GA: }{ }^{1} \\
\$ 3.75 \text { monthly flat fee for residential properties }\end{array}$ \\
\hline Tier & $\begin{array}{l}\text { Consumers categorized based on a selected } \\
\text { variable (e.g., land use, area, etc.) }\end{array}$ & $\begin{array}{l}\text { City of Le Seuer, MN } 2019 \text { monthly rates: }{ }^{2} \\
0-0.5 \text { acre: } \$ 6.38 \\
0.5-1.0: \$ 8.50 \\
1.0-5.0: \$ 29.75 \\
>5.0 \text { acres: } \$ \$ 42.50\end{array}$ \\
\hline \multicolumn{3}{|l|}{ Variable Rate } \\
\hline $\begin{array}{l}\text { Equivalent } \\
\text { Residential Unit } \\
\text { (ERU) }\end{array}$ & $\begin{array}{l}\text { Based on impervious area determined by the } \\
\text { Average impervious area of a Single Family } \\
\text { Residential parcel }\end{array}$ & $\begin{array}{l}\text { Village of Clemmons, } \mathrm{NC}:^{3} \\
1 \text { ERU }=3952 \mathrm{sq} \mathrm{ft} . \\
\$ 5 \text { per ERU monthly } \\
\text { Residential: } \$ 5 \\
\text { Non-residential: } \$ 5 \times \text { No. of ERUs }\end{array}$ \\
\hline $\begin{array}{l}\text { Residential } \\
\text { Equivalent } \\
\text { Factor (REF) }\end{array}$ & Based on the amount of runoff & $\begin{array}{l}\text { City of Champlin, MN: }{ }^{4} \\
\$ 7.50 / \text { acre per REF monthly } \\
\text { Low-density residential unit }(1 / 3 \text { acre): } \\
\$ 2.50 \text { monthly } \\
\text { Commercial parcels have a REF of } 2.28\end{array}$ \\
\hline Square foot & Based on the parcel sq. $\mathrm{ft}$. of imperviousness & $\begin{array}{l}\text { City of Kyle, TX monthly rates: }{ }^{5} \\
\text { Residential: } \$ 5 \\
\text { Commercial: } \$ 0.0021 \text { per sq. ft. of } \\
\text { impervious cover }\end{array}$ \\
\hline Water usage & $\begin{array}{l}\text { Fee assessed based on water meter or } \\
\text { water usage }\end{array}$ & $\begin{array}{l}\text { Village of Northbrook, IL: }{ }^{6} \\
\$ 1 \text { per } 1000 \text { gallons of water consumed }\end{array}$ \\
\hline Combination & & \\
\hline $\begin{array}{l}\text { Combination of } \\
\text { a tiered and an } \\
\text { ERU fee }\end{array}$ & $\begin{array}{l}\text { Tiered fees for residential properties and ERU } \\
\text { rate for non-residential properties }\end{array}$ & $\begin{array}{l}\text { Northeast Ohio Regional Sewer District rates } \\
\text { for 2019: } 7 \\
\text { Residential: } \\
\text { Tier 1: } \$ 3.09 \\
\text { Tier 2: } \$ 5.15 \\
\text { Tier 3: } \$ 9.27 \\
\text { Non-residential: } \$ 5.15 \text { per ERU }\end{array}$ \\
\hline $\begin{array}{l}\text { Combination of } \\
\text { water usage and } \\
\text { ERU fee }\end{array}$ & $\begin{array}{l}\text { Water usage fee for properties with a meter and } \\
\text { ERU for other properties based on } \\
\text { impervious area }\end{array}$ & $\begin{array}{l}\text { Bozeman, MT monthly rates: }{ }^{8} \\
\text { Properties with a water meter: } \$ 3.23 \text { per meter. } \\
\text { Properties without water meter: } \\
1 \text { ERU }=2700 \text { sq. } \mathrm{ft} \text {. } \\
\$ 2.68 \text { per ERU } \\
\text { Single-Family residential: } \$ 2.68 \\
\text { Multi-Family/Commercial: } \$ 2.68 \times \text { No. of ERUs }\end{array}$ \\
\hline
\end{tabular}

Notes: Information retrieved from the webpages: ${ }^{1}$ Clayton County Water Authority. Rates, Fees \& Billing for residential Accounts. ${ }^{2}$ City of Le Sueur, MN. Request for Council Action. ${ }^{3}$ The Village of Clemmons, NC. Stormwater Funding. ${ }^{4}$ WSB \& Associates, Inc. [36]. ${ }^{5}$ City of Kyle. Kyle's Storm Drainage \& Flood Risk Mitigation Utility. ${ }^{6}$ Village of Nortbrook. Northbrook Stormwater Utility. ${ }^{7}$ Northeast Ohio Regional Sewer District. Regional Stormwater Management Program. ${ }^{8}$ Bozeman, MT. Stormwater Division, Learn About My Utility Bill. 
Table 2. Examples of the Types of Credits and Discounts.

\begin{tabular}{llc}
\hline \multirow{2}{*}{ BMPs } & \multicolumn{2}{c}{ Impact Reduction } \\
\cline { 2 - 3 } & Volume Reduction & Water Quality \\
\hline Vegetation & & $\mathrm{X}$ \\
$\quad$ Dry or Wet Ponds & $\mathrm{X}$ & $\mathrm{X}$ \\
Dry or Wet Swales & $\mathrm{X}$ & $\mathrm{X}$ \\
Green roofs & $\mathrm{X}$ & $\mathrm{X}$ \\
Infiltration trenches & $\mathrm{X}$ & $\mathrm{X}$ \\
Rain gardens & $\mathrm{X}$ & $\mathrm{X}$ \\
Vegetated swales & & \\
\hline Storage & $\mathrm{X}$ & \\
Rain barrels & $\mathrm{X}$ & $\mathrm{X}$ \\
Ponds & & $\mathrm{X}$ \\
\hline Infiltration & $\mathrm{X}$ & $\mathrm{X}$ \\
Pervious pavers & $\mathrm{X}$ & $\mathrm{X}$ \\
Soak away pits & & $\mathrm{X}$ \\
Filter strips & & $\mathrm{X}$ \\
Manufactured underground filters & & \\
Sand filters & & \\
\hline Education E Outreach & & \\
Public education and outreach & & \\
Taking on maintenance responsibility & & \\
\hline
\end{tabular}

\section{The Evaluation of Stormwater Utility Fees}

In the public finance literature, revenue evaluation criteria are used to evaluate mechanisms for generating revenue [41,42]. This evaluation framework has been used to evaluate other revenue generating mechanisms $[43,44]$. There is little systematic research on the use of SUFs as a funding strategy for stormwater management. Therefore, in this study, we adapt this framework to evaluate the SUF strategy on four typical criteria of revenue evaluation: Efficiency, equity, revenue adequacy, and feasibility (see Table 3). We use the existing literature to assess the extent to which evidence is available that SUFs lead to efficient use of resources, are equitable, sustainable, and feasible to implement. We also identify gaps in the literature that need to be addressed to help municipalities make more informed decisions. 
Table 3. Evaluation Framework.

\begin{tabular}{|c|c|c|}
\hline & Criterion & Sample Questions \\
\hline \multirow[t]{2}{*}{ Efficiency } & & Does the fee lead to a change in behavior? \\
\hline & & Does the fee promote or hinder economic development? \\
\hline \multirow{3}{*}{ Equity } & Benefit received & Are the ratepayers direct beneficiaries of the services? \\
\hline & & Is the fee amount proportional to the costs/service? \\
\hline & Ability to pay & How regressive is the fee for different income groups? \\
\hline \multirow{6}{*}{ Sustainability } & Adequacy & How much revenue does it raise? \\
\hline & & $\begin{array}{l}\text { Is the revenue sufficient for maintaining and improving } \\
\text { the system? }\end{array}$ \\
\hline & Potential for growth & To what extent can the revenue keep up with rising costs? \\
\hline & & To what extent can the revenue keep up with inflation? \\
\hline & Stability and predictability & How stable is the revenue? \\
\hline & & How predictable is the revenue? \\
\hline \multirow{4}{*}{ Feasibility } & Political feasibility & How visible is the fee to the public? \\
\hline & & What are the legal barriers? \\
\hline & Administrative feasibility & How costly is establishing and administering the fee? \\
\hline & & Is it hard for the public to maintain compliance with the policy? \\
\hline
\end{tabular}

\subsection{Efficiency}

This criterion refers to the extent to which SUFs may lead to operational and economic efficiency. Operational efficiency refers to the efficient use of municipal resources available for stormwater management, and economic efficiency refers to the extent to which SUFs promote economic development in municipalities where they are adopted. While the primary objective of implementing SUFs is to generate revenue to address stormwater runoff and water quality, they have the potential to lead to efficient use of resources through changing public behavior. In this section, we assess the extent to which evidence is available that stormwater utilities lead to change in public behavior, reduction in the amount of runoff, and hence, reduction in cost of stormwater management and efficient use of resources. We also explore the impact of increasing SUF and the adoption of BMPs on property values.

SUFs have the potential to promote the adoption of on-site Best Management Practices (BMPs) and therefore, reduce the overall costs of stormwater management for the municipality. However, there is little empirical evidence that explores whether they actually promote BMPs. Some authors argue that when fees are proportional to the percentage of impervious material, it can discourage development that increases runoff [45]. Others argue that higher fees could encourage property owners to adopt BMPs to reduce the property's impervious area $[5,27]$, considering that property owners choose the less expensive option between adopting BMPs and paying the fee [46]. Evidence on this area is limited. Lindsey [6]'s findings suggest that only industrial users would consider the construction of on-site BMPs, under several assumptions. Therefore, further research is needed to assess the extent to which SUFs result in behavioral changes.

In addition, when municipalities combine SUFs with credits and discounts, they encourage property owners to adopt on-site stormwater management. This can also lead to efficient use of stormwater management resources. These practices reduce the impervious area on new constructions or when existing properties are remodeled. The adoption of BMPs can reduce the amount of runoff and decrease the public cost of providing stormwater management. However, credits and discounts must be designed in such a way as to incentivize property owners. This is particularly important for residential properties, in which fees are generally low, and such incentives may be insufficient to motivate property owners [28]. 
Similarly, SUFs may impact property values; however, there is limited research on this. A study on the impact of a shift from meter-based to parcel-based billing system in the city of Philadelphia found that the aggregate property values decreased by $\$ 190$ million for private non-residential properties after the increase in the fee [47]. On the other hand, some studies show positive impacts on property values attributed to the adoption of low-impact development or BMPs. For instance, Ward et al. [48] studied the impact of a natural draining system (NDS) in Seattle and found that residential properties with NDS project experienced an increase of between $3.5 \%-5 \%$ in their values as compared to similar properties without NDS projects.

SUFs can also promote or hinder economic development. Some authors argue that high fees for commercial and industrial properties may create incentives for businesses to relocate to other municipalities [5]. However, there is little empirical evidence on this. The city of Philadelphia study found that although businesses experienced increases in their stormwater fees as a result of the change from meter-based to parcel-based billing system, these increases did not provide them with sufficient incentives to relocate. Businesses, in particular, retail firms' decision to relocate are mostly influenced by competition and proximity to their customer base among other motives [47]. The study also argues that theoretically in the event of an increase in fee amount, businesses who lease a property and pay the stormwater fee would have the opportunity to renegotiate their rent amount during the lease renewal. But businesses that own the property will not have incentives to relocate as when they try to sell the property, they find that its market value has decreased. Therefore, in both cases, although the business is impacted, there is not enough incentive to relocate.

In addition, the adoption of BMPs in a parcel can generate indirect benefits or co-benefits through social contagion. For instance, Hunter and Brown [49] find that garden clustering occurs among neighbors with direct visual access to nearest neighbors' easement areas. They find that it is 2.4 times more likely that a property holds an easement garden if another property within its $30 \mathrm{~m}$ holds one. These BMPs, in addition to controlling runoff, can generate economic and social co-benefits such as creating a more sustainable urban environment, adding/improving the habitat for birds and pollinators, and improving aesthetics in the neighborhood [50].

\subsection{Equity}

The equity criterion assesses whether an SUF is considered fair in terms of its allocation of the costs and benefits. This criterion is assessed based on two principles: a benefit-received principle and the ability-to-pay principle [43].

In terms of the benefits-received principle, we assess the extent to which users pay in proportion to their runoff relative to the costs they impose on the system. As a user fee, the SUF is in principle highly equitable as compared to the traditional funding approach because tax-exempt properties such as non-profits, government entities, and other tax-exempt properties that are often big contributors to stormwater runoff can be charged [24]. However, depending on the fee type used, it can be more or less equitable. In the spectrum of fee structures, those fees tied to the amount of runoff are more equitable, while fees that charge a fixed amount regardless of the amount of runoff are less equitable. A combination of fee structures is somewhere in the middle. For instance, findings from [51] suggest that flat fees harm residential customers the most as they pay 10 times higher than they would under an ERU system. In addition, it is important to mention that fees can be set to favor one group over another. For instance, fees under a tiered or REF system can be set in a way that commercial properties pay more relative to their perceived impact on water quality [52].

An additional factor to consider under the benefit-received principle is that those who pay should be direct beneficiaries of the services they pay for. Since revenues from SUFs are earmarked exclusively for 
stormwater management purposes [53], the SUF complies with the benefit-received principle. However, this principle is eroded to the extent that certain groups of users do not pay their fair share. SUFs are paid by both tax-paying and tax-exempt properties, including federal properties [28]. There are some other properties, however, that are exempt from paying the fee such as airports and railroads [5], public streets and undeveloped land [38]. Given that these properties are often significant contributors to stormwater runoff, their exemption from paying a fee makes it less equitable to other ratepayers.

In terms of the ability-to-pay principle, we assess the relative burden to ratepayers based on their income. The literature does not discuss how regressive the SUFs are; however, we found one case where SUF affected low-income populations disproportionately. For instance, in Detroit U.S., stormwater fees led to water shutoff for low-income residents [54]. Some municipalities acknowledge the burden on low-income populations and have developed assistance programs to offset the additional burden. We found one program in the city of Portland, OR where the City offers sewer and stormwater bill discounts to families with less than $30 \%$ and $60 \%$ median family income (MFI). Only qualifying single-family properties can apply for the assistance and discounts are approved for 2 years [55]. According to Black and Veatch, in $2014,11 \%$ of the survey participants offered a low-income discount, $7 \%$ offered an elderly / senior citizen discount, $5 \%$ educational institutions discount, and 1\% disabled discount.

\subsection{Revenue Adequacy}

Local governments are constantly balancing stormwater management with other local services under their budget constraints. Whether SUFs can raise adequate funding is crucial to ensure effective stormwater management. Some argue that stormwater utility fees may generate adequate, sustainable, and more stable revenue as they are earmarked exclusively for stormwater management purposes and do not depend on annual budget appropriations $[10,53]$. However, several factors can challenge the revenue adequacy of SUFs.

First, SUFs should work towards full recovery of direct costs such as stormwater management, construction, and maintenance. In many cases, the fee does not generate sufficient funds to meet the stormwater needs of the municipality. According to a survey in 2014, out of 78 respondents with SUF, 62 percent indicated not having adequate funding to meet most of their needs (Black \& V, 2014). In the District of Columbia, for instance, revenues from the SUF only cover a fraction of the District's actual infrastructure costs [12]. Second, when not tied to inflation, stormwater utility fees lose their purchasing power and do not keep up with the increasing costs of providing stormwater management. In the same survey, 31 percent of respondents indicated not having any rate increases since 2004. Therefore, as the costs of providing the service increase, the funding gap is exacerbated [8]. Finally, stormwater utility discounts and credits can affect revenue adequacy. For instance, in southeastern U.S. (excluding Florida), discounts reduced the rate paid by an average of $25.6 \%$ [56]. To ensure adequate revenue generation, municipalities using a stormwater fee discount commonly set a maximum percentage for the discount [37].

\subsection{Feasibility}

Feasibility is assessed based on two criteria, political feasibility and administrative feasibility. In terms of political feasibility, one of the major challenges of implementing stormwater fees is gaining public approval. SUFs have high visibility due to the cost of their development and implementation regardless of being called service fees, taxes, or assessments [13]. In addition, the knowledge gap between policymakers and the public have resulted in low support for establishing stormwater fees. The public is often unsure of how they would benefit from the service [13].

Legal challenges also hinder political feasibility. In 2013, the University of Western Kentucky identified 72 legal challenges against stormwater fees in the U.S., of which 16 cases resulted in unfavorable decisions 
and in 44 the fee prevailed [30]. The existence of these challenges is acknowledged by several authors [24], but only NACWA provides a comprehensive list of municipalities and the description of the challenges experienced in each site from 1989 to 2016. Generally, all legal arguments related to stormwater utility fees fall under two main categories: The authority to enact, implement, and fund stormwater utility fees and the legality of the mechanism.

The first category includes challenges to the authority to enact, implement, and fund stormwater as well as issues related to sovereign immunity. In several states, the authority of the agency in charge of SUFs has been questioned, but in most of the cases, the agency has been able to demonstrate its authority. Several legal cases related to this category include the limited authority of municipalities. For instance, the City of Durham, NC was challenged because it was authorized to collect fees to finance certain structural parts of the stormwater program, but not to finance the operation of the program. Similarly, there are legal cases related to local and regional agencies' authority to impose fees on federal, state, and Indian tribal properties. Regarding federal properties, there was a debate about whether the CWA waived the government's sovereign immunity. Congress passed an amendment in 2011 clarifying federal responsibility for stormwater charges [30]. Legal challenges on this matter question the payment of stormwater charges before the amendment.

The second category includes challenges in terms of fees as an illegal tax, and the methodology used to calculate rates. Usually, establishing a new tax requires approval through a voter referendum or legislative approval. In most of the related legal cases it is claimed that the stormwater fee was imposed without previous approval from voters and therefore, it is illegal. Courts in most of the cases have ruled that stormwater charges are users fees. To distinguish fees from taxes, courts evaluate SUFs on the basis of their purpose, benefits to ratepayers, and costs to the government. In addition, several municipalities have been challenged by property owners for the methodology used to calculate the fee. For instance, the method of calculating the fee based on the impervious area was questioned in the City of Durham, NC; the City of Lewiston, ME; and the City of El Paso, TX [30].

In terms of administrative feasibility, other barriers that challenge the implementation of stormwater utility fees are administrative and compliance costs, particularly when establishing variable fees. Administrative costs include the creation of a division, usually within the department of public works, and hiring additional staff to administer the fee, as well as the creation/maintenance of a regularly updated GIS data to assess the fee (case studies report). Flat fees are often easier to administer, while variable fees require the municipality to develop a fee that is applicable to each property category. Additional costs may include establishing a billing system. Some municipalities either add the fee as a separate line item into existing utility bills such as water/sewer or, as a non-ad valorem assessment. The first approach is easier and less expensive to administer [18], and therefore, a more commonly used method.

\section{Discussion and Future Research Agenda}

Systematic research on the use of utility fees as a funding mechanism for stormwater management is limited. Future research is needed in order to fill some of the gaps discussed below to better assess SUFs under the revenue evaluation framework presented in this paper. Addressing these gaps will help municipalities make more informed decisions when establishing SUFs to implement stormwater management programs.

In terms of efficiency, there is a lack of research that explores the effects of SUFs on public behavior and their extent, as well as their effect on more efficient use of resources, particularly the impact of SUFs in the adoption of BMPs in different properties, including residential, commercial, and industrial properties. Similarly, there is a lack of research on the impact of SUFs on new construction designs. For instance, whether or not new constructions incorporate green infrastructure or BMPs into the designs. In addition, 
studies are needed to assess the effect of SUFs on property value and businesses. Lastly, studies are needed to assess long-term changes in stormwater investments in a municipality. If BMPs are adopted, this could potentially decrease investments in stormwater management. Studies are needed about municipalities where SUFs are new or relatively new, or where the rate structure has changed, or where the fee has significantly increased.

Regarding equity, there is no research that explores what fee types are more equitable in terms of benefit-received principle. In addition, future studies are needed to investigate the impact of SUFs on different income groups. Similarly, there is a need for further research on the use of stormwater discounts and assistance programs and how these features affect people in different income groups, in particular, low-income populations.

With respect to revenue sustainability, studies have found that stormwater utility fees are often not adequate to meet the increasing needs. Therefore, when establishing SUFs, it is important to set fees that are enough to maintain and improve the current stormwater infrastructure while not overburdening low-income customers. However, no research explores the composition of revenues to fund stormwater management, the distribution of revenues from SUFs between capital and operating expenses, and whether the revenues are adequate to fund stormwater management programs. Additionally, there is a lack of research on the extent to which revenues from SUFs can keep up with rising costs, inflation, and land development.

As to feasibility, there is a need for updating the legal considerations expressed in NACWA in order to inform municipalities about recent/new barriers that can challenge the implementation of SUFs. Similarly, an investigation of how municipalities design SUFs to avoid or minimize legal challenges would benefit other municipalities considering implementing such fees. Similarly, in terms of administrative feasibility, there is a need for research that focuses on whether it is hard for the public to comply with the policy.

\section{Conclusions}

SUFs are becoming increasingly used as an alternative method to fund stormwater management across the U.S. municipalities. Two of the most common methods used by municipalities to calculate stormwater fees are the impervious area of a property and the amount of runoff produced by it. Similarly, the use of stormwater credit programs is becoming prevalent to encourage stormwater BMPs, lower the burden of SUFs on low-income populations, and reduce the overall cost of stormwater management to the community. Municipalities generally offer two types of credits; for impact reduction and cost reduction.

We apply the revenue evaluation criteria to assess SUFs as a funding strategy. As a public finance instrument, SUFs have several advantages. First, SUFs have the potential to lead to a change in public behavior and efficient use of municipal resources. Second, SUFs can be more equitable than the traditional property tax approach as users pay relative to the runoff generated. However, this varies with its implementation. For instance, charging all users a flat fee brings less equity into the funding system. In addition, it is critical to consider residents' ability to pay when establishing SUFs. Third, revenues from SUFs are stable and sustainable as they are earmarked exclusively for stormwater management purposes. However, factors such as the ability to recover direct costs, the ability to keep up with inflation, and the extent of stormwater discounts and credits challenge the revenue adequacy.

There are some drawbacks, however. About its feasibility, one of the major challenges of implementing SUFs is gaining public and political approval. SUFs have high visibility due to the design and implementation costs, and often the public is unsure of the benefits they would receive from it. Other issues municipalities face when implementing SUFs are legal challenges related to the authority to enact them and the legality of the mechanism. To overcome these drawbacks, it is crucial to inform and involve the public into the decision-making processes. 
Future academic research is needed to better assess the efficacy of SUFs. In terms of efficiency, further research is important in order to explore the effects of SUFs on public behavior and their extent, as well as their effect on more efficient use of resources. With respect to equity, there is a lack of research on the fee types that are more equitable in terms of benefit-received principle, as well as their impact on different income groups. As to revenue adequacy, currently no research explores local stormwater management budgeting. Lastly, regarding feasibility, there is a research gap regarding variations in the use of SUF revenues across municipalities as well as effective SUF designs that can avoid or minimize legal challenges.

Author Contributions: Conceptualization, J.Z.; methodology, J.Z.; writing—original draft preparation, C.F. and R.Z.; writing-review and editing, J.Z., C.F. and R.Z.; visualization, J.Z., C.F. and R.Z.; supervision, J.Z.; project administration, J.Z.

Funding: This research was supported by NSF SRN: Integrated Urban Infrastructure Solutions for Environmentally Sustainable, Healthy and Livable Cities, Award number: 1444745.

Conflicts of Interest: The authors declare no conflict of interest.

\section{References}

1. Goonetilleke, A.; Thomas, E.; Ginn, S.; Gilbert, D. Understanding the Role of Land Use in Urban Stormwater Quality Management. J. Environ. Manag. 2005, 74, 31-42. [CrossRef] [PubMed]

2. Walsh, C.J.; Roy, A.H.; Feminella, J.W.; Cottingham, P.D.; Groffman, P.M.; Morgan, R.P. The Urban Stream Syndrome: Current Knowledge and the Search for a Cure. J. N. Am. Benthol. Soc. 2005, 24, 706-723. [CrossRef]

3. Zgheib, S.; Moilleron, R.; Chebbo, G. Priority Pollutants in Urban Stormwater: Part 1-Case of Separate Storm Sewers. Water Res. 2012, 46, 6683-6692. [CrossRef] [PubMed]

4. Walsh, C.J.; Booth, D.B.; Burns, M.J.; Fletcher, T.D.; Hale, R.L.; Hoang, L.N.; Livingston, G.; Rippy, M.A.; Roy, A.H.; Scoggins, M.; et al. Principles for Urban Stormwater Management to Protect Stream Ecosystems. Freshwater Sci. 2016, 35, 398-411. [CrossRef]

5. Fedorchak, A.; Dymon, R.; Campbell, W. The Financial Impact of Different Stormwater Fee Types: A Case Study of Two Municipalities in Virginia. J. Am. Water Resour. Assoc. 2017, 53, 1483-1494. [CrossRef]

6. Lindsey, G. Charges for Urban Runoff: Issues in Implementation. J. Am. Water Resour. Assoc. 1990, 26, 117-125. [CrossRef]

7. National Research Council. Urban Stormwater Management in the United States; National Research Council: Washington, DC, USA, 2008.

8. Black and Veatch. 2014 Stormwater Utility Survey; Report; Black and Veatch Management Consulting LLC: Overland Park, KS, USA, 2014.

9. Copeland, C. Green Infrastructure and Issues in Managing Urban Stomwater; Technical Report; Congressional Research Service: Washington, DC, USA, 2016.

10. Cameron, J.; Cincar, C.; Trudeau, M.; Marsalek, J.; Schaefer, K. User Pay Financing of Stormwater Management: A Case-study in Ottawa-Carleton, Ontario. J. Environ. Manag. 1999, 57, 253-265. [CrossRef]

11. LeClere, J. Trends in Managing Stormwater Utilities: The Practice of Watershed Protection; Technical Note 91; Center for Watershed Protection: Ellicott City, MD, USA, 2000; pp. 500-502.

12. Environmental Protection Agency. Managing Wet Weather with Green Infrastructure; Technical Report; Environmental Protection Agency (EPA): Washington, DC, USA, 2008.

13. National Association of Flood and Stormwater Management Agencies. Guidance for Municipal Stormwater Funding; Technical Report; National Association of Flood and Stormwater Management Agencies: Washington, DC, USA, 2006.

14. Campbell, C.W. Western Kentucky University Stormwater Utility Survey 2007; Technical Report; Western Kentucky University: Bowling Green, KY, USA, 2007.

15. Campbell, C.W. Western Kentucky University Stormwater Utility Survey 2018; Technical Report; Western Kentucky University: Bowling Green, KY, USA, 2018. 
16. O'Neill, S.J.; Cairns, S. New Solutions for Sustainable Stormwater Management in Canada; Report; Sustainable Prosperity: Ottawa, ON, Canada, 2016.

17. Grigg, N.S. Stormwater Programs: Organization, Finance, and Prospects. Public Works Manag. Policy 2013, 18, 5-22. [CrossRef]

18. Environmental Protection Agency. Funding Stormwater Programs; Technical Report EPA 901-F-09-004; Environmental Protection Agency: Washington, DC, USA, 2009.

19. Environmental Consulting and Technology, Inc. A Business Model Framework for Market-Based Private Financing of Green Infrastructure; Technical Report; Great Lakes Protection Fund: Gainesville, FL, USA, 2014.

20. North Carolina Forest Service. What Are BMPs? North Carolina Forest Service: Raleigh, NC, USA, 2017.

21. Environmental Protection Agency. Guidance Manual for Developing Best Management Practices BMP; Technical Report EPA 833-B-93-004; Environmental Protection Agency: Washington, DC, USA, 1993.

22. PennFuture. Funding Stormwater Management in Pennsylvania Municipalities: Creating Authorities and Implementing Ordinances; Technical Report; PennFuture: Harrisburg, PA, USA, 2017.

23. Busco, D.; Lindsey, G. An Internet Guide to Financing Stormwater Management; Technical Report; Center for Urban Policy and the Environment, Indiana University: Bloomington, IN, USA, 2001.

24. Brisman, A. Considerations in Establishing a Stormwater Utility; Southern Illinois University Law Journal: Carbondale, IL, USA, 2002.

25. Kea, K.; Dymond, R.; Campbell, W. An Analysis of Patterns and Trends in United States Stormwater Utility Systems. J. Am. Water Resour. Assoc. 2016, 52, 1433-1449. [CrossRef]

26. Doll, A.; Scodari, P.F.; Lindsey, G. Credits as Economic Incentives for On-Site Stormwater Management: Issues and Examples; Technical Report; Indiana University, School of Public and Environmental Affairs: Indianapolis, IN, USA, 2002.

27. Thurston, H.W. Opportunity Costs of Residential Best Management Practices for Stormwater Runoff Control. J. Water Resour. Plan. Manag. 2006, 132, 89-96. [CrossRef]

28. Kertesz, R.; Green, O.O.; Shuster, W.D. Modeling the Hydrologic and Economic Efficacy of Stormwater Utility Credit Programs for U.S. Single Family Residences. Water Sci. Technol. 2014, 70, 1746-1754. [CrossRef] [PubMed]

29. Kane, J.; Shivaram, R. As Flood Risks Intensify, Stormwater Utilities Offer a More Resilient Solution. Brookings Institute. 2017. Available online: https:/ /www.brookings.edu/blog/the-avenue/2017/09/21/as-flood-risksintensify-stormwater-utilities-offer-a-more-resilient-solution/ (accessed on 14 January 2019).

30. NACWA. Navigating Litigation Floodwaters: Legal Considerations for Enacting, Implementing, and Funding Stormwater Programs; Technical Report; National Association of Clean Water Agencies: Washington, DC, USA, 2016.

31. California Stormwater Quality Association. Creating a Stormwater Utility; California Stormwater Quality Association: Menlo Park, CA, USA, 2019.

32. Fuss \& O'Neill. Technical Memorandum 2 Evaluating the Role of Stormwater Utility Districts in the Implementation of Low Impact Development; Project No. 20091464.a10; Fuss \& O’Neill: Manchester, CT, USA, 2010.

33. New England Environmental Finance Center. Stormwater Utility Fees: Considerations E Options for Interlocal Stormwater Working Group (ISWG); Economics and Finance: Portland, ME, USA, 2005.

34. Environmental Protection Agency. Getting to Green: Paying for Green Infrastructure; Technical Report EPA 842-R-14-005; Environmental Protection Agency: Washington, DC, USA, 2014.

35. Campbell, C.W. Western Kentucky University Stormwater Utility Survey 2017; Technical Report; Western Kentucky University: Bowling Green, KY, USA, 2017.

36. WSB \& Associates, Inc. Stormwater Utility Fee; Justification Report 1684-24; City of Champlin: Minneapolis, MN, USA, 2008.

37. Environmental Protection Agency. Green Infrastructure Case Studies: Municipal Policies for Managing Stormwater with Green Infrastructure; Technical Report EPA-841-F-10-004; Environmental Protection Agency: Washington, DC, USA, 2010.

38. Black and Veatch. 2016 Stormwater Utility Survey; Report; Black and Veatch Management Consulting LLC: Overland Park, KS, USA, 2016. 
39. City of Urbana. City of Urbana Stormwater Utility Fee Credit and Incentive Manual; City of Urbana: Urbana, IL, USA, 2012.

40. Natural Resources Defense Council. How to: Stormwater Credit Trading Programs; Issue Brief; Natural Resources Defense Council: New York, NY, USA, 2016.

41. Musgrave, R.A.; Musgrave, P.B. Public Finance in Theory and Practice, 5th ed.; The McGraw-Hill Companies: New York, NY, USA, 1988.

42. Mikesell, J. Fiscal Administration, 10th ed.; Cengage Learning: Belmont, CA, USA, 2018.

43. Zhao, Z.J.; Das, K.V.; Larson, K. Tax Increment Financing as a Value Capture Strategy in Funding Transportation. J. Transport. Res. Board 2010,1-7. [CrossRef]

44. Coyle, D.D.; Robinson, F.O.; Zhao, Z.J.; Munnich, L.W.; Lari, A.Z. From Fuel Taxes to Mileage-Based User Fees: Rationale, Technology, and Transitional Issues; Final Report; Center for Transportation Studies, University of Minnesota: Minneapolis, MN, USA, 2011.

45. Kriz, K.A.; Bartle, J. Combined Sewer Overflow Affordability Project. In American Society for Public Administration, National Conference; University of Nebraska Omaha: Omaha, NE, USA, 2007.

46. Tietenberg, T.H. Economic Instruments for Environmental Regulation. In Economics of the Environment; Stavins, R., Ed.; W. W. Norton 'I\&' Company: New York, NY, USA, 2005; pp. 279-301.

47. Econsult Corporation. Economic Analysis of Stormwater Fee Changes on Philadelphia Business; Technical Report; Philadelphia Water Department: Philadelphia, PA, USA, 2012.

48. Ward, B.; MacMullan, E.; Reich, S. The Effect of Low-Impact-Development on Property Values. Sustainability 2008. [CrossRef]

49. Hunter, M.C.R.; Brown, D.G. Spatial Contagion: Gardening along the Street in Residential Neighborhoods. Landsc. Urban Plan. 2012, 105, 407-416. [CrossRef]

50. City of Minneapolis. City of Minneapolis Stormwater and Sanitary Sewer Guide; Technical Report; City of Minneapolis: Minneapolis, MN, USA, 2017.

51. Campbell, C.W. Western Kentucky University Stormwater Utility Survey 2016; Technical Report; Western Kentucky University: Bowling Green, KY, USA, 2016.

52. Campbell, C.W. Western Kentucky University Stormwater Utility Survey 2014; Technical Report; Western Kentucky University: Bowling Green, KY, USA, 2014.

53. Natural Resources Defense Council. Making It Rain: Effective Stormwater Fees Can Create Jobs, Build Infrastructure, and Drive Investment in Local Communities; Technical Report; Natural Resources Defense Council: New York, NY, USA, 2018.

54. Detroit Metro Times. Two Sets of Rules in Detroit Water Shutoffs, Detroit Metro Times. 2014. Available online: https: / / www.metrotimes.com/detroit/two-sets-of-rules-in-detroit-water-shutoffs/Content?oid=2202707 (accessed on 17 December 2018)

55. City of Portland. Bill Discount, 2019. Available online: https://www.portlandoregon.gov/water/article/565238 (accessed on 21 January 2019)

56. Southeast Stormwater Association. 2013 Southeast Stormwater Utility Survey; Technical Report; Southeast Stormwater Association: Suwanee, GA, USA, 2013.

(C) 2019 by the authors. Licensee MDPI, Basel, Switzerland. This article is an open access article distributed under the terms and conditions of the Creative Commons Attribution (CC BY) license (http:/ / creativecommons.org/licenses/by/4.0/). 